\title{
Correlation between PCNA and AgNOR scores in non-Hodgkin's lymphomas using sequential staining technique
}

\author{
F G Smith, P G Murray, J Crocker
}

\begin{abstract}
Aims: To investigate the relation between the numbers of interphase silver stained nucleolar organiser regions (AgNORs) and immunolabelling with the monoclonal antibody PC10, which demonstrates proliferating nuclei by reacting with proliferating cell nuclear antigen (PCNA).

Methods: The established sequential technique for the demonstration of interphase AgNORs and of antigens in paraffin wax sections was applied to a small series of non-Hodgkin's lymphomas (NHL) of both low and high grade type, together with specimens of palatine tonsil. The numbers of PCNA positive cells were counted in all specimens; in the tonsils the cells were counted in both follicle centres and in the interfollicular areas. The numbers of AgNORs in both PCNA positive and PCNA negative nuclei were then counted.
\end{abstract}

Results: Lower numbers of PCNA positive cells were found in the low grade than the high grade NHL $(18-28 \cdot 4 \%$ and $34 \cdot 2-51 \cdot 3 \%$, respectively). This was reflected in the two areas of the palatine tonsils, the counts being higher in the follicle centre nuclei than in those in the interfollicular compartments. In general, the numbers of AgNORs were higher in the PCNA positive nuclei than in those lacking the antigen; however, a consistent finding was that relatively high AgNOR scores were observed in PCNA negative nuclei, especially in the high grade lymphomas. In the tonsils, however, the AgNOR counts were much lower in the nuclei lacking PCNA than in those containing it.

Conclusions: The results obtained in the lymphomas were rather unexpected as, in general, previous studies have shown a close direct or indirect relation between AgNOR scores and proliferating cell counts. An explanation for these findings may be that the argyrophil proteins associated with proliferating cells remain in the nucleus in detectable form longer than the PCNA antigen, at least in neoplastic tissue.

(f Clin Pathol 1993;46:28-31)

The scoring of interphase NOR numbers using the argyrophil (AgNOR) technique ${ }^{1}$ has been shown to be of use in assessing the degree of malignancy in neoplasms. ${ }^{2-4}$ In the case of non-Hodgkin's lymphomas (NHL), AgNOR numbers can help to distinguish between high and low grade lymphomas ${ }^{56}$ with greater scores in the high grade than in the low grade types. However, the reason for the increased count in the high grade lymphomas was not originally fully understood. In view of the constant chromosomal positions of NORs, it might be expected to reflect cell ploidy, but there is now a great volume of evidence showing that interphase AgNOR scores represent the level of cell proliferation.

NORs are ribosomal DNA cistrons found in the short arms of the five human acrocentric chromosomes $\left(13,14,15,21\right.$ and 22). ${ }^{2-4}$ During interphase the NORs are represented by nucleolar fibrillar centres which appear as black "dots" of varying size when stained by the AgNOR method. This technique makes use of the fact that NOR associated proteins bind silver.

The double staining method using monoclonal antibodies and the argyrophil technique $^{1}$ has helped to overcome the problem of the heterogeneity of neoplasms by allowing the identification of cells before AgNOR enumeration. We applied this method to NHL using the PCNA antibody PC10. Unlike the Ki67 antibody which has previously been used in the double staining of NHL, ${ }^{7}$ this PCNA antibody reacts with paraffin wax sections and is not limited to frozen sections.

\section{Methods}

Normal palatine tonsils and a series of four low grade and six high grade NHL were selected from the files at East Birmingham Hospital. These had been fixed for between 24-48 hours in $10 \%$ formol-saline and taken to paraffin wax in the usual way. Sections were cut at $3 \mu \mathrm{m}$ thickness, allowed to adhere to glass slides at room temperature, and then incubated at $37^{\circ} \mathrm{C}$ overnight. Sections were then dewaxed and taken to water.

Sections were incubated in mouse monoclonal anti-PCNA antibody (Dako PC10) at a dilution of 1 in 100 in TRIS-buffered saline (TBS) ( $\mathrm{pH} \mathrm{7.6)}$ and then washed in TBS. PCNA was visualised using the standard alkaline phosphatase-anti-alkaline phosphatase (APAAP) labelling method. ${ }^{8}$ Adjacent sections were also stained for $T$ cell activity by means of a polytypic antibody to CD3 (Dako) and B cell content with a monoclonal antibody to CD20 (Dako L26).

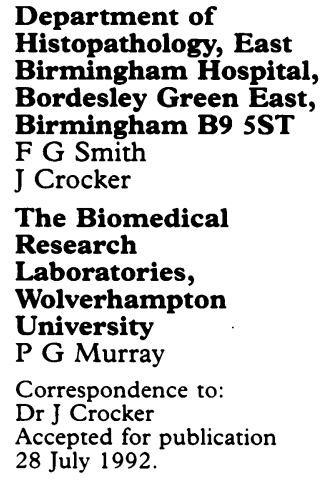

Correspondence to: Dr J Crocker Accepted for publication 28 July 1992 . 
After the sections were washed in distilled deionised water for 10 minutes, standard AgNOR staining was performed. ${ }^{5910}$ Incubation at room temperature in AgNOR staining colloid was extended to two hours to improve contrast. Sections were washed twice in distilled water for 10 minutes each and mounted in aqueous mounting medium.

Sections were examined under a $\times 100$ oil immersion objective lens. AgNORs were counted in 200 PCNA positive and PCNA negative cells in each case, this number having been reached by the standard continuous mean technique. In each of the tonsils, counts were performed separately for the germinal centres and interfollicular areas. Nuclei were taken as being positive only if there was un unequivocal, intense red reaction product. The differences between PCNA scores in the different groups of specimens and between AgNOR counts for different cell groups were analysed by means of confidence interval analysis.

\section{Results}

A positive reaction to the PCNA antibody resulted in an intense red colouration of the nucleus. The AgNORs showed up as black
Figure 1 Tonsillar follicle centre, showing mainly PCNA positive (red) nuclei, most of which contain multiple black dot-like "AgNORs".

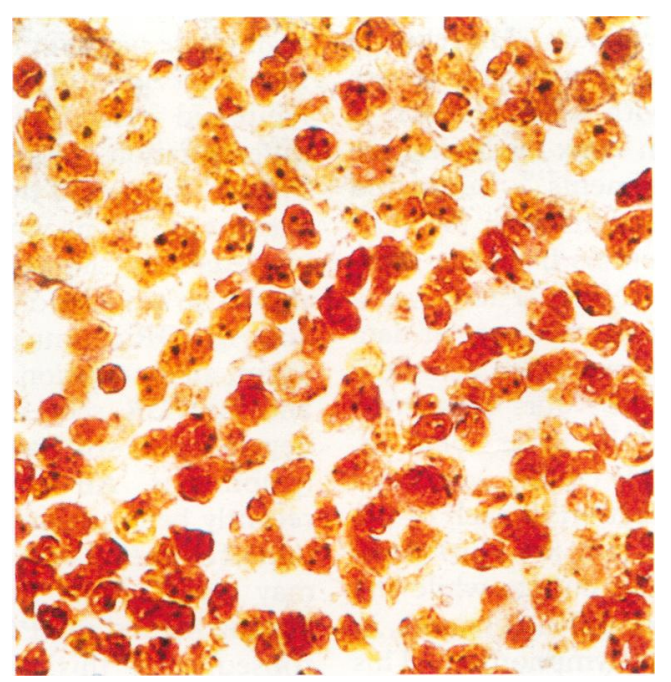

Figure 2 Centroblastic lymphoma, showing large PCNA positive (red) nuclei, containing multiple "AgNORs". Some PCNA negative nuclei also have several AgNOR sites. "dots" of variable size. (figs 1 and 2). The lymphomas were all of $B$ cell phenotype as shown by CD 20 staining and where there was an intervening "reactive" $\mathrm{T}$ lymphocytic infiltration these (CD3-positive) cells had only 1.0 to $1.5 \mathrm{AgNOR}$ dots per nucleus and accounted for no more than $5 \%$ of the total cell count.

In the high grade lymphomas the PCNA positive cells ranged from $34 \cdot 2$ to $51 \cdot 3 \%$. These positive cells had mean AgNOR scores from 5.66 to 9.93 , while the PCNA negative cells had a mean AgNOR score from 2.76 to 6.62 (table).

In the low grade lymphomas PCNA positive cells ranged from $18 \cdot 0$ to $28 \cdot 4 \%$. The positive cells had mean AgNOR scores from 5.4 to 8.39 , while the PCNA negative cells had a mean AgNOR score from 1.49 to 4.63 (table).

The PCNA score in tonsillar follicle centres ranged from 43.0 to $50.0 \%$ while in the interfollicular areas it was 2.0 to $7.5 \%$. In follicle centre cells the AgNOR scores for the PCNA positive nuclei were from 1.9 to 6.89 and in interfollicular cells the range was from 1.67 to 6.79 . The cells lacking PCNA activity in follicle centres had a mean AgNOR score of 2.09 to 3.05 ; in the interfollicular PCNA negative cells the AgNOR score was from 1.45 to 1.67 (table).

Although the numbers of specimens were small, the quantity of data permitted statistical evaluation. At a $95 \%$ confidence interval, the difference between the AgNOR scores in PCNA positive and negative cells in high grade lymphomas was significant at $p<0.05$. In low grade lymphomas, the difference between the AgNOR scores in PCNA positive and negative specimens was significant at $p<0.01$. In interfollicular and follicle centre cells of the tonsil there was a significant difference in AgNOR counts between PCNA positive and negative cells at $\mathrm{p}<0.01$ for both types of cells.

\section{Discussion}

The counting of AgNORs is becoming increasingly used in tumour histology for assessing the degree of malignancy and consequently, in some cases, also for the prognosis and treatment of the patient. Many methods, including electron microscopy, enzyme histochemistry, immunochemistry, morphometry and DNA flow cytometry have been used to help with the grading of NHL, and within recent years NOR enumeration has also been of value in their assessment. The high grade lymphomas have higher AgNOR scores than the low grade specimens. ${ }^{56}$ So far the reason for this observation is not completely understood. It was originally presumed that high AgNOR scores could represent cell ploidy, which is known often to be excessive in NHL. To test this idea DNA flow cytometry was performed on both high and low grade lymphomas, ${ }^{11}$ comparing the mean AgNOR count with the DNA index and the percentage of $S$ phase cells (proliferating cell numbers). There was no correlation between the AgNOR score and DNA aneuploidy $(r=0 \cdot 14)$, but the AgNOR score 
Mean AgNOR scores in PCNA postiive and PCNA negative cells

\begin{tabular}{|c|c|c|c|}
\hline Specimen & $\begin{array}{l}\% P C N A \\
\text { positive cells }\end{array}$ & $\begin{array}{l}\text { Mean AgNOR score in } \\
\text { PCNA postive cells } \\
\text { (Range) (SEM) }\end{array}$ & $\begin{array}{l}\text { Mean AgNOR score in } \\
\text { PCNA negative cells } \\
\text { (Range) (SEM) }\end{array}$ \\
\hline $\begin{array}{l}\text { Centroblastic } \\
\text { Centroblastic } \\
\text { Immunoblastic } \\
\text { Immunoblastic } \\
\text { Immunoblastic } \\
\text { Lymphoblastic } \\
\text { Lymphocytic } \\
\text { Centrocytic } \\
\text { Centroblastic/centrocytic } \\
\text { Centroblastic/centrocytic } \\
\text { Tonsil FC } \\
\text { IF } \\
\text { Tonsil FC } \\
\text { IF } \\
\text { Tonsil FC } \\
\text { IF } \\
\text { Tonsil FC } \\
\text { IF }\end{array}$ & $\begin{array}{r}39 \cdot 7 \\
44 \cdot 7 \\
51 \cdot 3 \\
37 \cdot 9 \\
34 \cdot 2 \\
41 \cdot 5 \\
28 \cdot 4 \\
18 \cdot 0 \\
19 \cdot 3 \\
26 \cdot 3 \\
46 \cdot 5 \\
2 \cdot 0 \\
50 \cdot 0 \\
7 \cdot 5 \\
43 \cdot 0 \\
3 \cdot 0 \\
45 \cdot 0 \\
7 \cdot 0\end{array}$ & $\begin{array}{l}9.93(4-15)(0.27) \\
5.66(3-10)(0.16) \\
9.06(5-14)(0.18) \\
8.59(4-18)(0.26) \\
8.93(4-22)(0.41) \\
9.24(5-16)(0.27) \\
5.40(3-10)(0.23) \\
7.71(4-11)(0.29) \\
7.71(5-12)(0.25) \\
8.39(5-14)(0.32) \\
5.16(2-9)(0.16) \\
3.75(3-5)(0.48) \\
1.90(2-10)(0.19) \\
1.67(2-8)(0.45) \\
6.80(3-11)(0.23) \\
3.13(2-12)(1.40) \\
6.89(2-11)(0.21) \\
6.79(4-10)(0.48)\end{array}$ & $\begin{array}{l}6.62(1-9)(0.21) \\
2.78(1-7)(0.14) \\
5.32(1-9)(0.20) \\
4.12(1-9)(0.18) \\
5.30(1-10)(0.19) \\
4.63(1-9)(0.21) \\
1.49(1-5)(0.07) \\
2.78(1-9)(0.17) \\
4.63(1-8)(0.16) \\
3.11(1-9)(0.18) \\
2.09(1-6)(0.10) \\
1.55(1-5)(0.06) \\
2.34(1-6)(0.12) \\
1.45(1-4)(0.05) \\
2.96(1-7)(0.14) \\
1.67(1-6)(0.07) \\
3.05(1-7)(0.14) \\
1.54(1-4)(0.06)\end{array}$ \\
\hline
\end{tabular}

$\mathrm{FC}=$ follicle centre; $\mathrm{IF}=$ interfollicular area. lines that cell proliferation alone is related to AgNOR numbers. ${ }^{2122}$ However, in these experiments the total amount of argyrophilia was calculated and not the number of AgNORs; as not all argyrophilia is due to transcriptionally active molecules the amount may not necessarily change in proportion to the cells' proliferative state. It seems that some of the AgNOR associated proteins to which the silver binds may have structural roles.

In the current study we have further investigated the relation between AgNOR scores and cell proliferation using the PCNA antibody which unlike Ki67 reacts with paraffin wax sections. We found that the proliferating PCNA positive cells had higher AgNOR scores than the PCNA negative cells, and that both the numbers of PCNA positive cells and AgNORs were greater in high grade lymphomas than low grade lymphomas. However, the AgNOR counts were relatively high in PCNA negative cells $(1 \cdot 5-6 \cdot 6)$ compared with counts in non-proliferating cells as shown by the interfollicular counts in the tonsil sections $(1 \cdot 5-1 \cdot 7)$. The PCNA negative cell scores of the NHL specimens were also greater than the PCNA negative scores in the tonsil germinal centres $(2 \cdot 1-3 \cdot 0)$. This may indicate that PCNA and AgNORs are presented at different stages of the cell cycle or may linger for different durations after mitosis. It is of interest that the cells lacking PCNA in both low and high grade lymphomas may still have relatively increased AgNOR scores compared to resting lymphoid cells. This may reflect a lack of differentiation rather than entry into cell cycle. ${ }^{20}$ The small numbers of reactive $T$ cells present in the specimens would appear to have low AgNOR scores. Thus although we have shown an association between PCNA labelling and AgNOR counts in NHL and therefore, yet again, an association between cell proliferation and AgNOR scores, it appears that PCNA negative cells still have relatively high counts in lymphomas. An identical phenomenon has recently been demonstrated in hyperproliferation of epithelial cells of the rat stomach. ${ }^{23}$ This may result from the production of NORs lagging behind the PCNA epitope production; consequently this requires further investigation. It remains a mystery, however, to account for the apparently close relation which has been shown on several occasions between AgNOR and Ki67 counts for a variety of tumours. We still have much to pursue in relation to our understanding of the interrelations between the increasingly large numbers of proposed "markers" of cell proliferation.

We are indebted to Dako (UK) Ltd for their generous financial support for the colour illustrations.

1 Murray PG, Boldy DAR, Crocker J, Ayres JG. Sequential demonstration of antigens and AgNORs in frozen and paraffin sections. I Pathol 1989;159:169-72.

2 Anon. NORs - a new method for the pathologist. Lancet 1987;i:1413-14.

3 Crocker J. Review: Proliferation indices in malignan lymphomas. Clin Exp Immunol 1989;77:299-308.

4 Crocker J. Nucleolar organiser regions in pathology. In: McGee J O'D, Wright NA, Eds. Oxford textbook of McGee J O'D, Wright NA, Eds. Oxford textbook of 1992:586-90.

AgNORs may have been due to their fusion which is known to occur during the cell cycle as cells exit from mitosis. None the less, it has been shown in a number of neuroblastoma cell 
5 Crocker J. Nar P. Nucleolar organiser regions in lymphomas. F Pathol 1987;151:111-8.

6 Crocker J, Egan MJ. Correlation between NOR sizes and numbers in non-Hodgkin's lymphomas. $f$ Pathol 1988;156:233-9.

7 Janmohamed RMI, Murray PG, Crocker J, Leyland MJ Sequential demonstration of nucleolar organiser regions and Ki67 immunolabelling in non-Hodgkin's lymphomas. Clin Lab Haematol 1990;12:395-9.

8 Taylor CR. Immunomicroscopy: a diagnostic tool for the surgical pathologist. Philadelphia: WB Saunders, 1986:67.

9 Crocker J, Skilbeck NQ. Nucleolar organiser region associated proteins in cutaneous melantic lesions: a quantitative study. $\mathcal{F}$ Clin Pathol $1987 ; 40: 885-9$.

10 Crocker J, McGovern J. Nucleolar organiser regions in normal, cirrhotic and carcinomatous livers. F Clin Pathol 1988;41:1044-8.

11 Crocker J, Macartney JC, Smith PJ. Correlation between DNA flow cytometric and nucleolar organiser region data in non-Hodgkin's lymphomas. F Pathol 1988;154:151-6.

12 Janmohamed RM, Armstrong SJ, Crocker J, Leyland MJ, Hulten MA. The relationship between number of interphase NORs and NOR bearing chromasomes in nonHodgkin's lymphoma. $\mathcal{F}$ Pathol 1988;1 158:3-7.

13 Crocker J. Nucleolar organiser regions. In: Underwood JCE, ed. Current topics in pathology. Heidelberg, SpringerVerlag. 1990:91-4.

14 Gerdes J, Dallenbach F, Lennert K, Lemke H, Stein H. Growth fractions in malignant non-Hodgkin's lymphomas (NHL) as determined in situ with the monoclonal mas (NHL) as determined in situ with the mo
antibody Ki67. Haematol Oncol 1984;2:365-71.

15 Gerdes J, Schwab J, Lemke H, Stein H. Production of a mouse monoclonal antibody reactive with a human nuclear antigen associated with cell proliferation. Int $\mathcal{F}$ Cancer 1983;31:13-20.

16 Hall PA, Crocker J, Watts A, Stansfield AG. A comparison of nucleolar organiser region staining and $\mathrm{Ki} 67$ immuno staining in non-Hodgkin's lymphomas. Histopathol 1988; 12:373-82

17 Arrighi FE, Lau Y-F, Spallone A. Nucleolar activity in differentiated cells after stimulation. Cytogenet Cell Genet 1980;26:244-50.

18 Youngshan Y, Stanley WS. Effect of differentiating agents on nucleolar organiser region activity in human melanoma cells. Cancer Genet Cytogenet 1988;31:251-62.

19 Reeves BR, Casey G, Honeycombe JR, Smith S Correlation of differentiation state and silver staining of nucleolar organisers in the promyelocytic leukaemia cell line HL60. Cancer Genet Cytogenet 1984;13:159-66.

20 Edwards S, Afford S, Crocker J. The effect of inducing agents on the numbers of interphase fibrillar centres in the U937 promonocytic cell line. Exp Cell Res 1991;194: 118-21

21 Derenzini M, Pession A, Farabegoli F, Trere D, Badiali M Dehan P. Relationship between interphasic nucleolar regions and growth rate in two neuroblastoma cell lines. Am f Pathol 1989;134:925-32.

22 Trere D, Pession A, Derenzini M. The silver stained proteins of interphasic nucleolar organiser regions as a parameter of cell duplication rate. Exp Cell Res 1989;184:131-7.

23 Grey MR, Darnton J, Hunt JA, Irlam RW, Williams DF, Kingsnorth AN. PCNA and AgNOR co-staining in accelerated proliferation lends insight into cell cycle events. Gastroenterology 1992;102:A358. 